\title{
The Persistence of Behavioral Sensitization to Cocaine Parallels Enhanced Inhibition of Nucleus Accumbens Neurons
}

\author{
Douglas J. Henry ${ }^{1}$ and Francis J. White ${ }^{2}$ \\ 1Department of Pharmacology, University of Washington, School of Medicine, Seattle, Washington 98195 and \\ ${ }^{2}$ Neuropsychopharmacology Laboratory, Department of Neuroscience, Finch University of Health Sciences, The \\ Chicago Medical School, North Chicago, Illinois 60664-3095
}

\begin{abstract}
The mesoaccumbens dopamine system is intricately involved in the locomotor stimulation produced by cocaine and sensitization of this effect following repeated cocaine administration. The mechanisms responsible for the expression of sensitized locomotion appear to involve alterations in both presynaptic (increased dopamine release) and postsynaptic (increased responsiveness of dopamine D1 receptors) aspects of dopamine neurotransmission within the nucleus accumbens. The present experiments used behavioral and single-cell electrophysiological techniques to determine the persistence of sensitization and of enhanced postsynaptic responses to cocaine within the nucleus accumbens following various periods of withdrawal from repeated cocaine treatment $(10 \mathrm{mg} / \mathrm{kg}$ i.p., twice daily, 14 d). Behavioral sensitization to the locomotor stimulant effects of cocaine was evident after $1 \mathrm{~d}, 1$ week, and 1 month, but not 2 months of withdrawal. A similar time course was observed for the enhanced efficacy of cocaineinduced inhibition of nucleus accumbens neurons, whether cocaine was administered systemically or locally by microiontophoresis. Nucleus accumbens neurons also exhibited sensitized inhibitory responses to iontophoretically applied GABA after $1 \mathrm{~d}$ of withdrawal, but not later times. These findings suggest that cocaine sensitization is relatively persistent, but not necessarily permanent, and support the hypothesis that expression of behavioral sensitization to cocaine involves actions within the NAc, particularly those mediated by dopamine D1 receptors.
\end{abstract}

[Key words: cocaine, dopamine, locomotor behavior, nucleus accumbens, sensitization, psychomotor stimulant, drug withdrawal, dopamine $D 1$ receptor]

Both the locomotor activating and positive reinforcing effects of cocaine are mediated, in large part, by midbrain ventral tegmental area (VTA) dopamine (DA) neurons projecting to the nucleus accumbens (NAc) (see Kalivas and Stewart, 1991; White and Wolf, 1991; Koob, 1992; Roberts, 1992, for recent reviews). Repeated intermittent administration of cocaine augments its locomotor activating effects (Post and Rose, 1976; Kilbey and

Received Mar. 10, 1995; revised May 16, 1995; accepted May 24, 1995.

This research was generously supported by the National Institute on Drug Abusc via USPIIS Grant DA-04093 and Research Scientist Development Award DA-00207 to F.J.W.

Correspondence should be addressed to Francis J. White, Ph.D., Department of Neuroscience, FUHS/CMS, 3333 Green Bay Road, North Chicago, IL 60064-3095.

Copyright 1995 Society for Neuroscience $0270-6474 / 95 / 156287-13 \$ 05.00 / 0$
Ellinwood, 1977; Kalivas et al., 1988) and, under certain conditions, its reinforcing efficacy (Woolverton et al., 1984; Lett, 1989; Horger et al., 1990). This behavioral sensitization also involves the mesoaccumbens DA pathway, and specific aspects of sensitization result from alterations in different components of the system. The development of sensitization is apparently initiated by processes occurring within the VTA. Although psychomotor stimulants injected into the VTA fail to induce locomotion, repeated intra-VTA injections induce sensitization to either systemic or intra-NAc injections of such drugs (Kalivas and Weber, 1988; Vezina and Stewart, 1990; Hooks et al., 1992; Perugini and Vezina, 1994), including cocaine (DuMars et al., 1988; Honks et al., 1992). In contrast, intra-NAc injections of psychomotor stimulants cause hyperactivity, but sensitization of this effect does not occur with repeated administration (Dougherty and Ellinwood, 1981; Kalivas and Weber, 1988; Hooks et al., 1992). However, the NAc is essential for expression of sensitization. Rats that receive repeated systemic or intra-VTA injections of psychomotor stimulants exhibit sensitization to intraNAc administration of such drugs (Hitzemann et al., 1980; Kolta et al., 1989; Paulson and Robinson, 1991; Perugini and Vezina, 1994).

The most widely accepted mechanism of sensitization is an enhanced ability of psychomotor stimulants to increase extracellular levels of DA within the NAc (see Robinson and Becker, 1986; Kalivas and Stewart, 1991; White and Wolf, 1991, for reviews). Ilowever, sensitized behavior occurs when there is no enhanced DA response, or even a diminished DA response (Segal and Kuczenski, 1992a,b; Wolf et al., 1992; Kalivas and Duffy, 1993a; Maisonneuve and Kreek, 1994), indicating that this mechanism is not solely responsible for sensitization. Another neuroadaptation which may contribute to the expression of sensitization is supersensitivity of DA D1 receptor-mediated responses within the NAc (Henry and White, 1992; White et al. 1992, 1995a). Repeated administration of cocaine (Henry et al., 1989; Henry and White, 1991) or amphetamine (Higashi et al., 1989; Wolf et al., 1994) increases the inhibitory efficacy of DA and DA D1 receptor-selective agonists on NAc neurons. The extent to which upregulation of DA D1 receptor-mediated neurophysiological effects occurs as a result of increased DA DI receptor density is a matter of debate (Kleven et al., 1990; Peris et al., 1990; Mayfield et al., 1992; Alburges et al., 1993; Unterwald et al., 1994), but even in its absence, alterations in intracellular signal transduction (Nestler et al., 1990; Terwilliger et al., 1991; Striplin and Kalivas, 1993) and gene transcription (Hope et al., 1992; Hope et al., 1994) within the NAc could lead to long-term alterations in DA D1 receptor-mediated signaling. 
Tests of neuronal adaptations at various times during and after repeated administration of psychomotor stimulants have provided important information regarding the sequence of mechanisms that is responsible for the induction and maintenance of behavioral sensitization (Ackerman and White, 1990; Peris et al., 1990; Paulson et al., 1991; Wolf et al., 1992; Kalivas and Duffy, 1993a,b). Our previous studies have demonstrated that the enhanced sensitivity of NAc DA D1 receptors was evident within $24 \mathrm{hr}$ of the last cocaine injection and persisted for 1 month, but not two months (Henry and White, 1991). Because behavioral sensitization is considered to be an enduring, if not permanent, phenomenon (Robinson and Becker, 1986; Post et al., 1992), the return of DA Dl receptors to a normosensitive state suggests that other mechanisms might also be responsible for behavioral sensitization at later withdrawal times. IIowever, the persistence of cocaine sensitization (Post et al., 1992), and of enhanced basal and cocaine-stimulated interstitial DA levels (Weiss et al., 1992), is a function of treatment regimen and test conditions. Therefore, the present study determined the withdrawal time course for enhanced behavioral and neuronal responses to cocaine following repeated cocaine administration.

\section{Materials and Methods}

Subjects. Male Sprague-Dawley rats (Harlan Sprague-Dawley, Indianapolis, IN) weighing 225-275 gm at the start of experiments were used in all studies. The animals were housed $2 /$ cage in metal hanging cages. Food and water were available ad libitum. The colony room was maintained at constant temperature $\left(21-23^{\circ} \mathrm{C}\right)$ and humidity $(40-50 \%)$ with a 12. hr light/12. hr dark cycle (07:00 on, 19:00 off). All experiments were performed in accordance with the Guide for the Care and Use of Laboratory Animals (NIH publication No. 85-23).

Repeated cocaine treatment protocol. Rats were randomly assigned to either a cocaine treatment or control group, housed in like-treated pairs and acclimated to the home environment for at least one week. All cocaine-treated rats received twice-daily (10:00 and 18:00) injections of cocaine $\mathrm{HCl}(10.0 \mathrm{mg} / \mathrm{kg}$, i.p.) for 14 consecutive days. Control subjects received equivalent volume injections $(1.0 \mathrm{ml} / \mathrm{kg})$ of the cocaine vehicle, deionized water, under an identical treatment regimen. Rats were given either behavioral or electrophysiological tests at various times after the last cocaine injection. For behavioral tests, the withdrawal periods were $20-24 \mathrm{hr}, 7 \mathrm{~d}, 30 \mathrm{~d}$, or $60 \mathrm{~d}$. Due to technical reasons, the withdrawal periods for electrophysiological tests were not as precise, but they were always conducted within $18-24,7-8 \mathrm{~d}, 30-$ $32 \mathrm{~d}$, and $60-64 \mathrm{~d}$ of the last treatment injection. Hereafter, these groups are referred to as the $1 \mathrm{~d}, 1$ week, 1 month, and 2 months groups. Separate groups of rats were tested at each of these four periods of withdrawal. In the behavioral studies, the first injection of cocaine was administered in the activity cages. All other injections were administered in the animal's home cage within a separate colony room.

Behavioral testing. Twelve photobeam horizontal locomotion detection devices (PAS monitoring system, San Diego Instruments, San Diego, CA) were mounted around standard rectangular transparent rodent cages $(30 \times 50 \mathrm{~cm})$. Each frame was equipped with three photoelectric beams which divided the long axis of the cage into four quadrants (12.5 $\times 30 \mathrm{~cm} \mathrm{each}$ ). Interruption of photobeams generated digital pulses which were computer analyzed to determine both the total number of photobeam interruptions as well as interruptions of consecutive photobeams (ambulations). All behavioral testing occurred between 16:00 and 19:00 hr with the overhead lights on within a separate and environmentally distinct room located in the animal colony. Each cxposure to the chamber consisted of a 30 min habituation period, followed by injection and a $90 \mathrm{~min}$ test period. Subjects were handled daily by the experimenter for 1 week prior to exposure to the testing boxes.

Acute behavioral effects of cocaine. To obtain baseline data regarding the locomotor stimulant effects of cocaine using our activity system, five separate groups of 12 rats each, weighing $250-275 \mathrm{gm}$, were injected with either $0,5,10,20$, or $40 \mathrm{mg} / \mathrm{kg}$ cocaine $\mathrm{HCl}$ (i.p.) and tested for locomotor activity for $90 \mathrm{~min}$, as described above. In addition to automated measures, qualitative indices of the behavioral effects of cocaine were obtained by trained observers unaware of the treatment con- ditions (dose). Each rat was observed for $10 \mathrm{sec}$ during each $5 \mathrm{~min}$ interval and the presence or absence of seven behaviors was noted: rearing (lifting the forepaws from the floor), sniffing upwards/outwards, sniffing downwards, "head-bobbing" (repetitive up/down or sideways movements of the head), licking, gnawing, and grooming.

Sensitization tests. All groups received an initial exposure to the test chambers in which the $30 \mathrm{~min}$ habituation period was followed by an intraperitoneal injection of drug vehicle and a $90 \mathrm{~min}$ test. The following day, rats in each group ( $n \geq 12$ /group) received the first injection of their treatment regimen (either cocaine or vehicle) in the behavioral chambers. After these two initial exposures to the testing apparatus, all treatment injections occurred in the colony room. For sensitization tests, both control and cocaine-treated rats were challenged with cocaine (10 $\mathrm{mg} / \mathrm{kg}$ i.p.). For the $1 \mathrm{~d}$ withdrawal groups, rats were injected $20-24 \mathrm{hr}$ after the last treatment injection. The next day, these rats were tested after vehicle injections to determine the possible existence of conditioned locomotion as a result of exposure to the test apparatus. After extended withdrawal periods ( 1 week to 2 months), rats were tested with vehicle the day before the cocaine challenge to rehabituate them to the chambers. All animals were also tested with vehicle on the day after the sensitization test to determine whether any conditioning to the locomotor-stimulant effects of cocaine was evident from the previous cocaine test day. By using these testing parameters, we were able to ascertain both between-groups sensitization and within-group sensitization.

Single-cell recording. The details for extracellular single cell recordings from NAc neurons have been detailed previously (Henry and White, 1991). Briefly, rats were anesthetized with chloral hydrate (400 $\mathrm{mg} / \mathrm{kg}$, i.p.) and mounted in a stereotaxic frame. Body temperature was maintained at $36-37^{\circ} \mathrm{C}$ by a thermostatically controlled heating pad. A lateral tail vein was catheterized for administration of cocaine and other drugs or additional anesthetic (as needed). A burr hole was drilled in the skull and the dura was retracted from the area overlying the NAc (0.8-2.0 $\mathrm{mm}$ lateral to the midline, $10.5-10.9 \mathrm{~mm}$ anterior to lambda), with the aid of stereotaxic coordinates (Paxinos and Watson, 1986). Micromanipulators were used to place the electrode $6.0 \mathrm{~mm}$ ventral to the cortical surface and a hydraulic microdrive was used for fine movements of the electrode tip within the limits of the NAc $(6.0-7.5 \mathrm{~mm}$ ventral to the cortical surface). Electrode signals were passed through a high impedance amplifier/filter and displayed on an oscilloscope. Individual action potentials ( $>3: 1$ signal:noise ratio) were detected with a window discriminator and monitored with an audio amplifier. A polygraph recorder was used to plot the integrated rate histograms generated by the output of the window discriminator. Digital counts were obtained for off-line analysis.

Microiontophoresis. Five-barrel glass electrodes were pulled and beveled (tip diameter of 4-7 $\mu \mathrm{m}$ ). The center (recording) barrel was filled with $2 \mathrm{M} \mathrm{NaCl}$ saturated with $1 \%(\mathrm{w} / \mathrm{v})$ fast green dye, resulting in an in vitro impedance of $2-6 \mathrm{M} \Omega$ measured at $135 \mathrm{~Hz}$. One side barrel was filled with $2 \mathrm{M} \mathrm{NaCl}$ and used for automatic current-balancing. A second side barrel was filled with L-glutamic acid monosodium salt $(0.05 \mathrm{M}, \mathrm{pH} 8)$ to stimulate quiescent NAc neurons. Glutamate was ejected in $20 \mathrm{sec}$ on $/ 20 \mathrm{sec}$ off pulses (5-30 $\mathrm{nA}$ as anion). The ejection current was adjusted until stable activity of 46 spikes/sec was observed for at least 4-6 min. A positive retaining current of $10 \mathrm{nA}$ was applied to the glutamate barrel during nonejection periods to minimize passive diffusion. The two remaining side barrels were filled with cocaine $(0.01$ $\mathrm{M}, \mathrm{pH} 4)$ and $\gamma$-aminobutyric acid (GABA, $0.01 \mathrm{M}, \mathrm{pH} 4)$.

After recording stable basal activity for $4-6 \mathrm{~min}$, cocaine or GABA was applied iontophoretically using continuous current which was doubled in amplitude every $80 \mathrm{sec}$. Each NAc neuron was tested sequentially with the two compounds, and each cell was allowed to recover from the inhibitory effects of the first drug to a new stable 4-6 min baseline before application of the second drug. The order of drug application was reversed from cell to cell within each animal. Data were expressed as the percent basal activity, which was determined by comparing the mean firing rate during the $80 \mathrm{sec}$ drug ejection period to the 4-6 min predrug period. During measurement of the basal glutamate-driven firing of NAc neurons and their responses to drugs, data were collected only during glutamate ejection periods. Cocaine and GABA were ejected as cations, and a negative retaining current of 10 $\mathrm{nA}$ was applied during nonejection periods. Ejection currents for cocaine ranged from 2-32 nA, below those at which obvious local anesthetic effects are apparent (White, 1987; White et al., 1993). GABA was applied in currents of 1-16 nA. Only Type I NAc neurons (White 

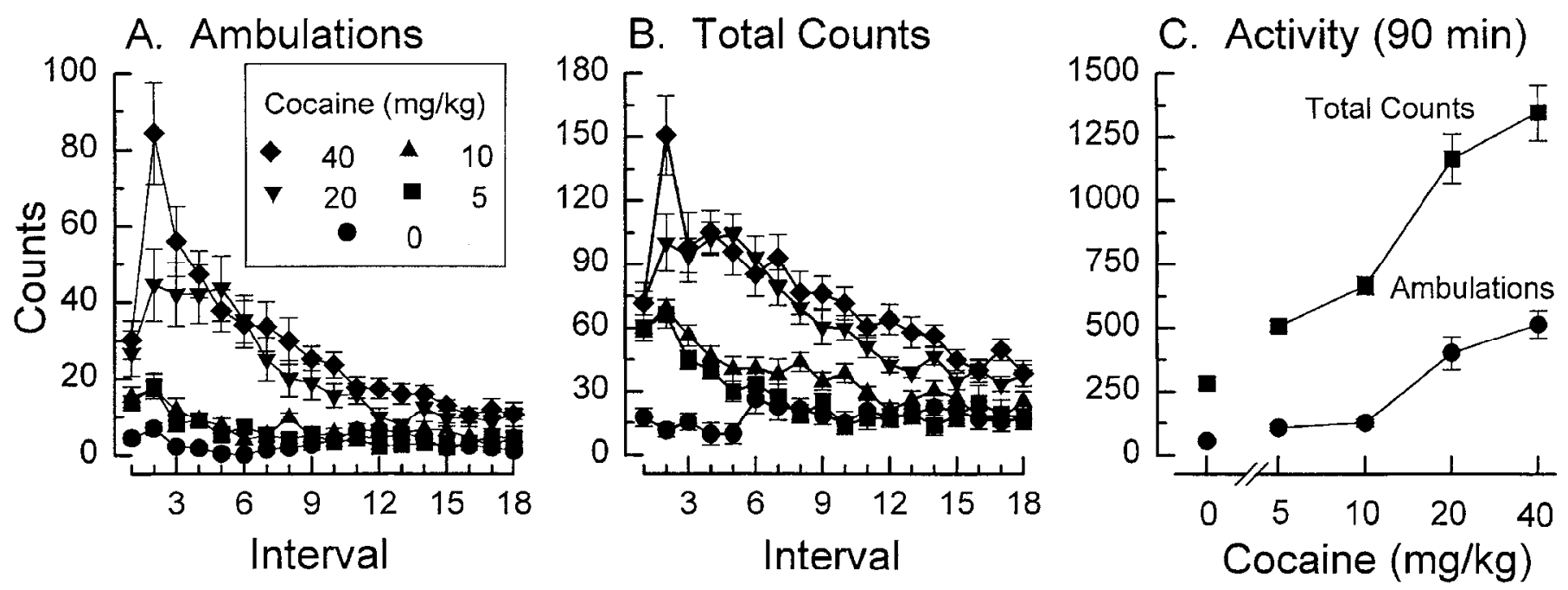

Figure I. Locomotor response to acute cocaine administration. Dose-dependent increases in ambulations $(A)$ and total activity $(B)$ illustrated for each $5 \mathrm{~min}$ interval of the $90 \mathrm{~min}$ test $(n=12 \mathrm{rats} /$ dose). $C$ presents the cumulative ambulation and total counts for the $90 \mathrm{~min}$ test at each dose of cocaine. In each panel, data points represent the mean \pm SEM from separate groups of rats.

et al., 1987, 1993), which comprise $90 \%$ of the population under our experimental conditions, were included in this study.

Intravenous cocaine challenge. For some experiments conducted in the $1 \mathrm{~d}$ and 2 month withdrawal groups, rats were tested with systemic (intravenous) cocaine. After monitoring stable spontaneous or glutamate-driven activity for 4-6 min, NAc neurons were challenged with intravenous cocaine at a cumulative dose range of $0.1-6.4 \mathrm{mg} / \mathrm{kg}$, with the dose doubled every $80-90 \mathrm{sec}$. Cocaine-induced inhibition of NAc neuronal activity was reversed by administration of the DA D1 receptor antagonist SCH 23390 (0.05 mg/kg, i.v.). Data from intravenous challenge experiments were expressed as percent basal or glutamate-driven activity.

Histology. After recording sessions, the position of the electrode tip was marked by passing a $25 \mu \mathrm{A}$ cathodal current through the recording barrel for $15 \mathrm{~min}$, which deposited a discrete spot of green dye. Rats were then deeply anesthetized with additional chloral hydrate (100-200 $\mathrm{mg} / \mathrm{kg}$, i.v.), and transcardially perfused with $0.9 \% \mathrm{NaCl}$ followed by $10 \%$ formalin. The brains were stored in $10 \%$ formalin until serial frozen sections ( $40 \mu \mathrm{m}$ thickness) were cut and subsequently stained with cresyl violet. Recording sites were then verified with the use of routine light microscopy. In intavenous studies, only one cell was recorded per rat. In iontophoretic experiments, 1-5 NAc neurons were recorded per rat and the dye spot marked the position of the last neuron recorded, which served as a reference point for the other neurons studied within that animal. When more than one NAc neuron was recorded in a given animal, the cells under study were separated by a minimum distance of $200 \mu \mathrm{m}$.

Statistics. The results of intravenous and microiontophoretic experiments were compared using a two-way (groups $\times$ dose) analysis of variance (ANOVA) with repeated measures on one variable (dose or current). Subsequent planned comparisons between specific control and treatment means were conducted using Dunnett's test. The results of acute dose/time response tests for behavioral activity were analyzed with a two-way ANOVA with repeated measures (time). For sensitization tests, comparisons of locomotor activity counts, either between (repeated cocaine vs vehicle for each withdrawal time) or within-groups, were made with unpaired or paired Student's two-tailed $t$ tests, respectively. Dose-response comparisons for observed behaviors were made with one-way ANOVA, followed by Newman-Keuls tests. Differences between groups with respect to observed behaviors were evaluated using Student's $t$ tests.

Materials. Cocaine $\mathrm{HCl}$, chloral hydrate, and L-glutamic acid monosodium salt were obtained from Sigma Chemical Co. (St. Louis, MO). GABA HCl was obtained from Calbiochem (La Jolla, CA). SCH 23390 $\mathrm{HCl}$ was purchased from Research Biochemicals, Inc. (Natick, MA). All compounds were dissolved in deionized water. All drugs were prepared fresh on the day of testing. All concentrations refer to the weights of the respective salts.

\section{Results}

\section{Acute behavioral effects of cocaine}

Because this was our initial study using the hehavioral testing apparatus to assess cocaine sensitization, we first determined the dose and temporal effects of cocaine on rat activity. As shown in Figure 1, acute cocaine administration caused significant ( $p$ $<0.00001)$ dose-dependent increases in both ambulation $\left(F_{4.55}\right.$ $=27.6)$ and total counts $\left(F_{4,55}=32.4\right)$. Temporal analysis indicated a significant $(p<0.00001)$ effect of time and a significant time $\times$ dose interaction for both ambulation $\left(F_{17,9.5 .5}=29.6\right.$ and $F_{68,935}=7.3$, respectively $)$ and total counts $\left(F_{17,935}=31.4\right.$ and $F_{68,935}=8.3$, respectively). For the two lowest doses of cocaine ( 5 and $10 \mathrm{mg} / \mathrm{kg}$ ), there was approximately three to four times more activity during the first $10 \mathrm{~min}$, as compared to the vehicle control. The effect gradually subsided to control values by $45 \mathrm{~min}$ postinjection. For the two higher cocaine doses ( 20 and $40 \mathrm{mg} / \mathrm{kg}$ ), the activation was markedly greater and morc prolonged. When the data were combined and presented for the entire $90 \mathrm{~min}$ test session, a clear parallel increase in ambulation and total counts was observed (Fig. 1C). Because this parallel relationship was observed in all experiments, only the ambulation results are depicted in subsequent figures.

The results shown in Figure 1 clearly show that, under the present experimental conditions, cocaine-induced increases in horizontal locomotion (ambulation) were monophasic. Thus, there was no apparent switch to more focused, nonambulatory types of stereotyped behaviors, such as stationary sniffing, licking, and gnawing, which would cause a decrease in ambulation counts at higher doses. Direct observation confirmed this interpretation. As shown in Figure 2, there were significant dosedependent (all $F_{4.55}$ values with $p<0.00001$ ) increases in four specific behaviors: rearing (31.4), sniffing upward/outward (18.1) sniffing downward (55.8), and hcad-bobbing (60.2). Cocaine did not elicit focused oral stereotyped behaviors (sniffing, gnawing) at any of the doses tested. Grooming responses were inconsistent and variable and did not show dose-dependent effects. For the four prevalent behaviors, the pattern of behavioral change increased dose-dependently except that at the largest dose tested $(40 \mathrm{mg} / \mathrm{kg}$ ), rearing and upward sniffing decreased 


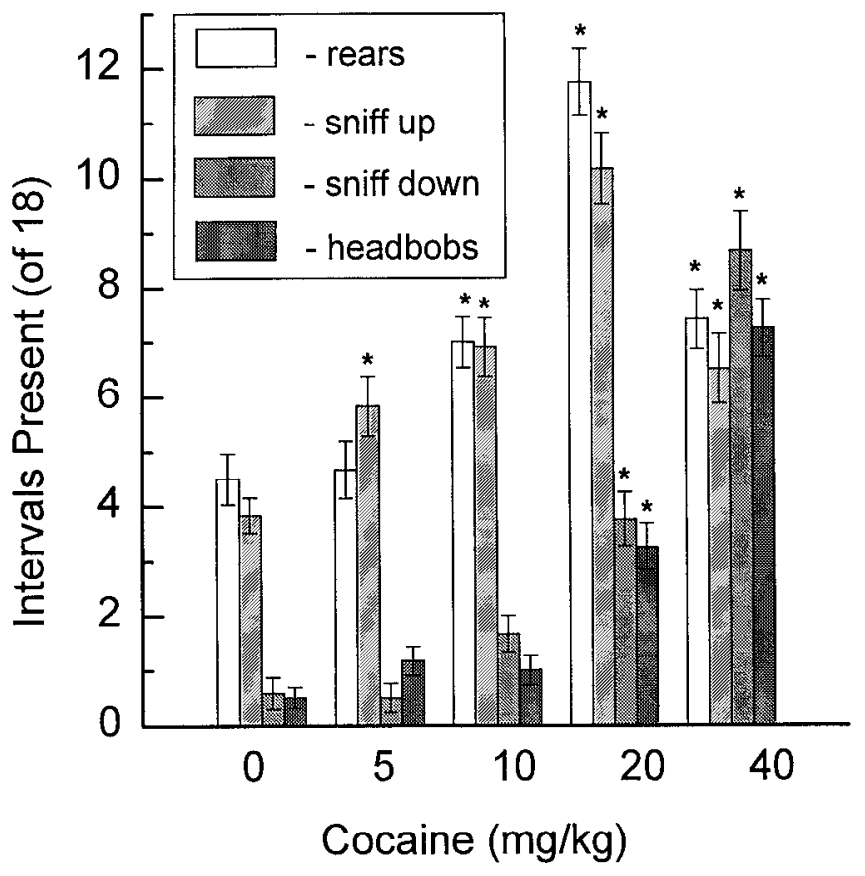

Figure 2. Increases in the presence of repetitive "stereotyped" behaviors following cocaine injections. Cocaine caused a dose-dependent monophasic increase in downward sniffing and "head bobbing." In contrast, rearing and upward sniffing reached a plateau at the $20 \mathrm{mg} / \mathrm{kg}$ dose and declined somewhat at the $40 \mathrm{mg} / \mathrm{kg}$ dose. Despite the presence of these stereotyped behaviors, ambulations continued to increase.

as compared to the $20 \mathrm{mg} / \mathrm{kg}$ dosc whercas downward sniffing and head bobbing increased. Despite the presence of this form of stereotyped behavior, the rats showed further increases in ambulation, indicating that they were not engaged in highly focused stereotyped behaviors that are incompatible with ambulation.

\section{Behavioral effects of cocaine after repeated cocaine administration}

As shown in Figure $3 A$, rats that received repeated cocaine injections exhibited significantly enhanced locomotor responses relative to vehicle-treated controls ( $n=18 /$ group) when challenged with cocaine after a one day withdrawal period $\left(t_{34}=\right.$ $3.28, p=0.0024)$. Sensitization within the cocaine treatment group was also evident since the rats exhibited a greater locomotor response to cocaine in their final exposure to the drug relative to their first exposure $\left(t_{17}=3.42, p=0.0033\right)$. When challenged with vehicle on the day after cocaine testing, both the vehicle $\left(t_{17}=4.17, p=0.0006\right)$ and cocaine groups $\left(t_{17}=\right.$ $9.87, p=0.0001$ ) exhibited responses that were significantly greater than the corresponding vehicle response observed during the habituation test, and from the Day 1 vehicle test for the control group $\left(t_{17}=5.13, p=0.0001\right.$, Fig. $\left.3 A\right)$. In fact, the degree of ambulation was indistinguishable from the locomotor response to an acute $10.0 \mathrm{mg} / \mathrm{kg}$ cocaine challenge (Fig. 1), suggesting that a single exposure to the combination of drug injection and the test environment resulted in a conditioned locomotor response to the test environment.

Following a 1 week withdrawal from cocaine or vehicle injections, a separate group of rats also exhibited sensitization to the locomotor-stimulant effects of cocaine (Fig. 3B), whether the comparison was made within the cocaine-treated group $\left(t_{11}=\right.$ $3.21, p=0.008)$, or between groups $\left(t_{22}=2.77, p=0.011, n\right.$
$=12$ group). Inlike the $1 \mathrm{~d}$ withdrawal group, hut similar to groups tested at all other withdrawal times, there appeared to be no conditioned response to the test environment in the 1 week withdrawal group, because cocaine-treated and control rats exhibited similar responses to vehicle challenge when tested on the habituation day and on the vehicle challenge day (day 8, Fig. $3 B)$.

After a 1 month withdrawal from cocaine or vehicle, a separate group of cocaine-treated rats also displayed significantly enhanced locomotor responses $\left(t_{30}=3.50, p=0.002\right)$ to cocaine challenge as compared to their matched control group (Fig. $3 C$ ). However, sensitization within the cocaine-treated group $(n=12)$ was not evident at this withdrawal time. Thus, the response to cocaine following a 1 month withdrawal was not significantly higher than the response to the initial injection of cocaine $\left(t_{11}=\right.$ $1.19, p=0.258$ ).

When tested following a 2 month withdrawal from cocaine or vehicle (Fig. 3D), separate groups of rats showed no evidence of sensitized locomotion to cocaine. Thus, neither the betweengroups comparison $\left(t_{22}=0.48, p=0.644\right)$ nor the within-group comparison was statistically significant $\left(t_{11}=0.47, p=0.651\right)$. Although the response of the control group to cocaine at this time point was not significantly different from that of the cocaine-treated group, it was higher than that observed in the other control groups. Thus, there did not appear to be a significant age-related decline in sensitivity to cocaine.

Temporal analysis of the effects of cocaine at each of the four withdrawal times indicated that sensitization consisted of a heightened locomotor response primarily during the first $30 \mathrm{~min}$ after cocaine injection (Fig. 4). There was no evidence for an altered temporal pattern of bchavior during the 90 min test pcriod as a function of repeated cocaine administration (Fig. 4), except perhaps a greater duration of heightened activity in the $1 \mathrm{~d}$ withdrawal group (Fig. 4A). Viewed together, Figures 3 and 4 indicate that sensitization produced by our treatment regimen was most evident immediately after the cessation of treatment (up to 1 week) and waned gradually until it was no longer apparent after a 2 month withdrawal period.

\section{Individual animal analyses}

Because the within-group and between-groups comparisons yielded different conclusions with respect to the presence of sensitization in the 1 month withdrawal group, we decided to analyze our data for the presence of sensitization in individual animals. This required setting a criterion to judge a rat as sensitized. To this end, we first ascertained the normal amount of session-to-scssion variability of cocainc responsiveness in nonsensitized rats. We used a separate groups of 12 rats and tested their response to $10 \mathrm{mg} / \mathrm{kg}$ of cocaine on two occasions $14 \mathrm{~d}$ apart. We chose the 2 week intertest interval based upon published results indicating that context-dependent sensitization that occurs following a single administration of cocaine persists only for several days (Post et al., 1992). Our findings support this conclusion because there was no evidence for sensitization across the two tests: first test, $134 \pm 24$; second test, $116 \pm 20$ (mean ambulation counts \pm SEM). The average percent change, regardless of direction, was $30.2 \%$ with a SD of $18.1 \%$. Accordingly, we chose as our criterion for a sensitized rat a percent increase in ambulation counts of at least $50 \%$, a value that was greater than $1 \mathrm{SD}$ above the mean of the average session-tosession variability. Based upon this criterion, we found the following percentages of sensitized rats in the various cocaine treat- 

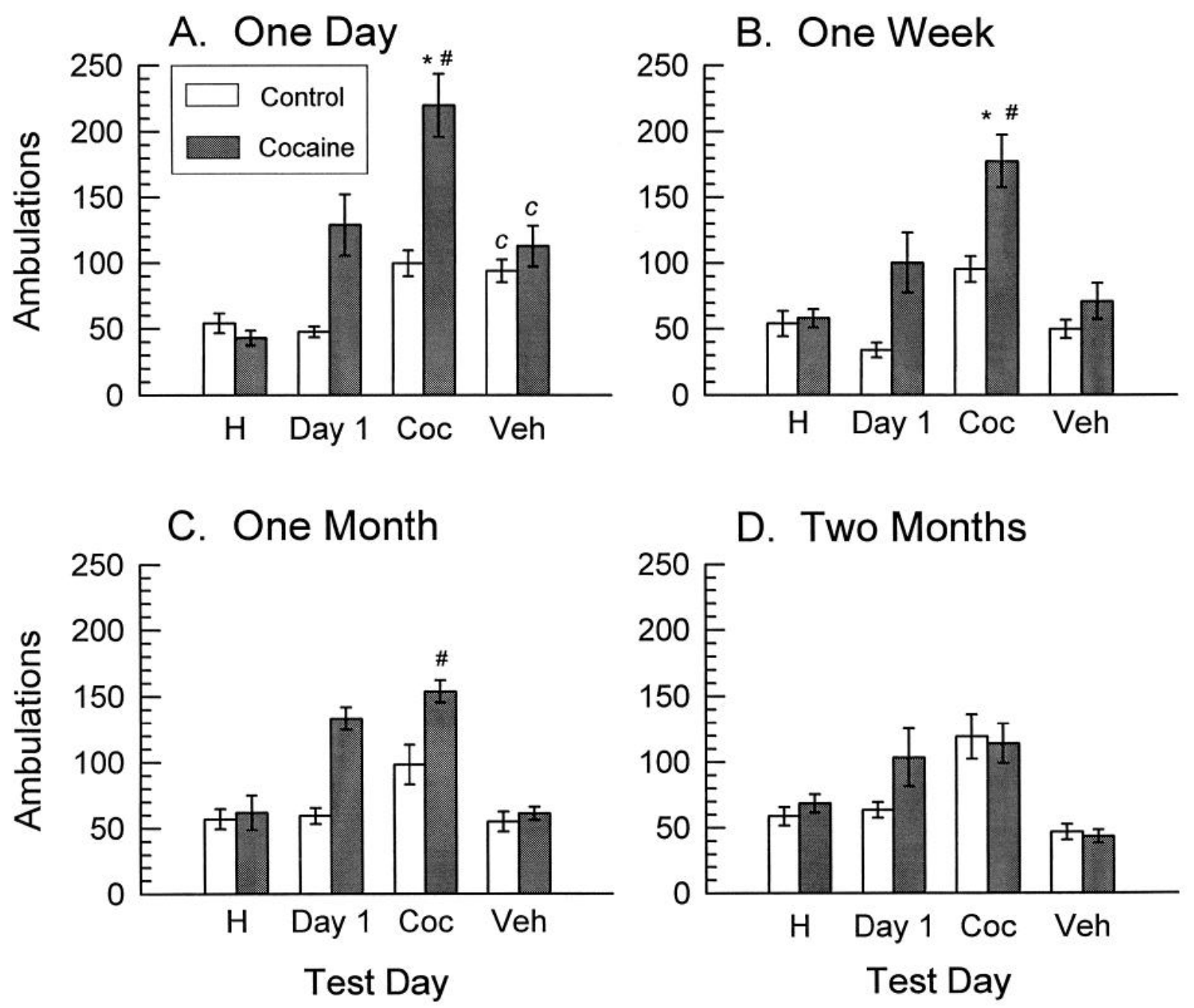

Figure 3. Effects of cocaine and vehicle injections on locomotor activity prior to and subsequent to repeated cocaine administration in the four different withdrawal groups: $A, 1 \mathrm{~d}(n=18) ; B, 1$ week $(n=12) ; C, 1$ month $(n=12)$; and $D, 2$ months $(n=12)$. All animals were injected with the cocaine vehicle and habituated to the testing apparatus the day prior to the start of repeated treatment $(H)$. Day $l$ represents the response to the first vehicle (control groups) or cocaine injection (cocaine groups) of the repeated treatment regimen. The Coc bars represent the cocaine challenge $(10 \mathrm{mg} / \mathrm{kg}$, i.p.) given to both the control and cocaine groups at the specified withdrawal times. The Veh bars represent the response to vehicle challenge on the day after the cocaine challenge. This protocol provided both a within-group and between-groups assessment of the presence of sensitization. Between-groups sensitization (\#) is evident at all but the 2 month withdrawal time whereas within-group sensitization (*) is evident only at the $1 \mathrm{~d}$ and 1 week withdrawal times. There was a significant increase in locomotor activity in response to the vehicle on the day after the cocaine challenge (Veh bars) only in the $1 \mathrm{~d}$ withdrawal group (c. Each bar represents the mean \pm SEM. See text for statistical significance information.

ment groups: $1 \mathrm{~d}, 78 \% ; 1$ week, $75 \% ; 1$ month, $50 \%$; and 2 months, $25 \%$. Of particular interest was the finding that four of the six nonsensitized rats in the 1 month group showed decreases in ambulation counts during the challenge test as compared to their first cocaine injection. This accounts for the lack of a significant within-subject sensitization in the 1 month withdrawal group.

\section{Additional tests after 2 months of withdrawal}

Because the lack of persistence of behavioral sensitization to cocaine is somewhat at odds with reports describing primarily amphetamine sensitization (see Discussion for details), we conducted additional experiments to determine other features of cocaine-induced behavior in similarly treated rats. Because the rats were tested for sensitization only at the 2 month withdrawal time, we could not be sure that they had been sensitized at earlier time points. It is also possible that sensitization was being ex- pressed as a qualitative alteration in the form of behavior rather than as a quantitative increase in locomotion. It is known that amphetamine sensitization can be expressed as a reduction in locomotion due to the elicitation of more focused stereotyped behaviors (see Discussion for details and references).

Two groups of randomly assigned rats $(n=16$ /group) received repeated cocaine or vehicle injections as described above. Half of the rats in each group were tested with cocaine $(10 \mathrm{mg} /$ $\mathrm{kg}$, i.p.) $20 \mathrm{hr}$ after the last (28th) cocaine injection. All rats were then tested following a 2 month withdrawal, as described above. The rats were tested in the locomotor activity cages and were scored, as above, by an observer who was blind to group assignments. As shown in Table 1, rats that were tested following a $1 \mathrm{~d}$ withdrawal not only showed greater ambulation and total counts as recorded automatically, but also engaged in significantly more rearing, sniffing and head bobbing than did their corresponding control group. However, following a 2 month 

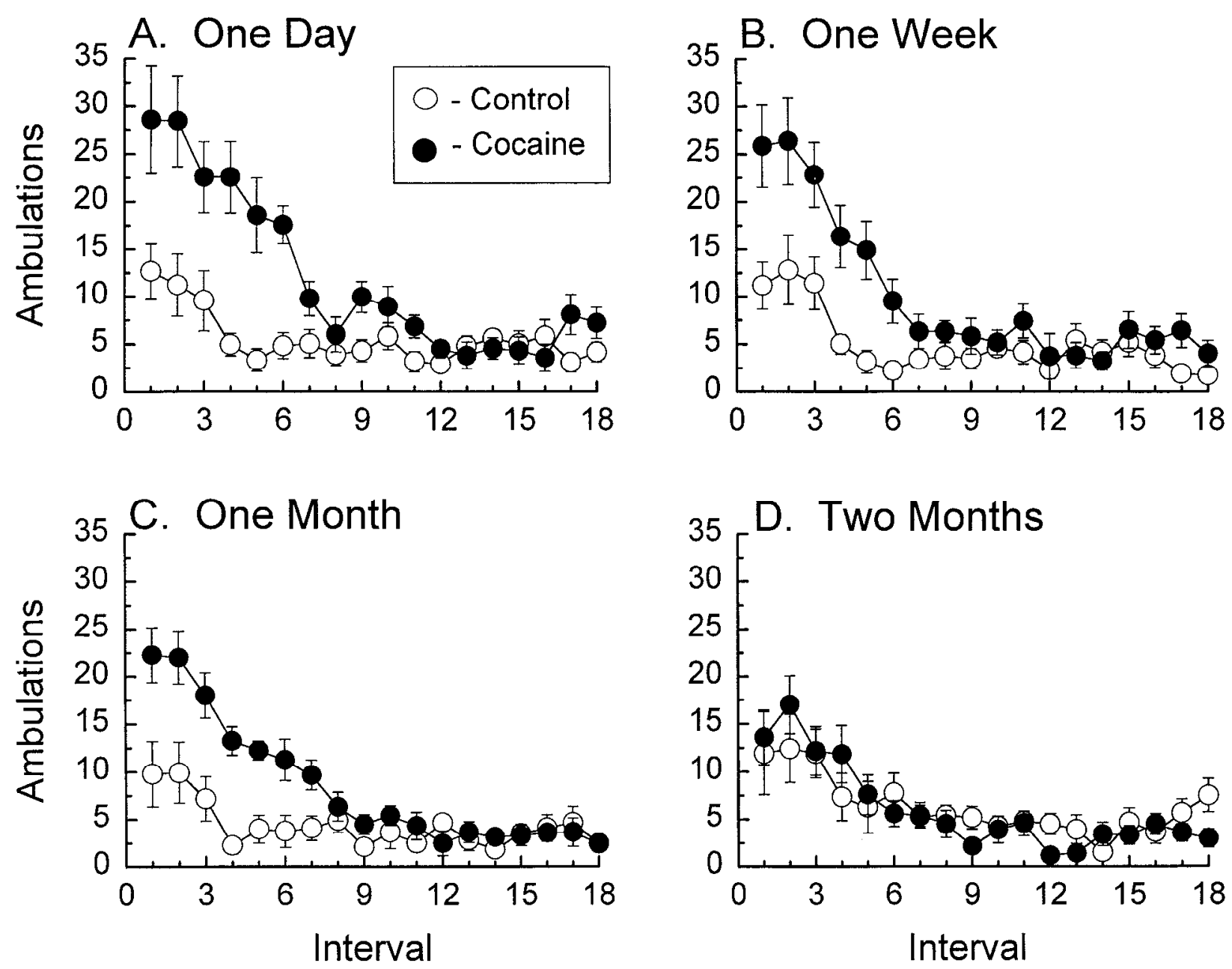

Figure 4. Time course for the locomotor responses to cocaine challenge $(10 \mathrm{mg} / \mathrm{lg}$, i.p.) at various withdrawal times after cessation of repeated treatment with either cocaine or vehicle (control). Cocaine sensitization was manifest as an increase in ambulatory responses primarily during the first 30-35 min after cocaine injection with no evidence for increased duration of the behavioral effect. Each point represents the mean \pm SEM.

withdrawal, the control groups as well both cocaine groups were essentially equivalent in all measures of behavior. Thus, the failure to observe sensitization following a two month withdrawal from our cocaine treatment regimen was probably not due to the failure to sensitize the rats at earlier time points or to the induction of qualitatively different, more intense forms of stereotyped behavior.
Electrophysiological experiments following repeated cocaine administration

Iontophoretic administration of cocaine inhibits the firing of most NAc neurons by preventing the reuptake of both endogenous DA and 5-HT (White, 1990; White et al., 1992, 1993). In the present experiments, we determined whether such inhibitory effects were enhanced at various withdrawal times following

Table 1. Lack of cocaine sensitization $(10.0 \mathrm{mg} / \mathrm{kg}$ challenge) following a 2 month withdrawal

\begin{tabular}{|c|c|c|c|c|c|c|}
\hline & & & \multicolumn{4}{|c|}{2 month withdrawal } \\
\hline & \multicolumn{2}{|c|}{$1 \mathrm{~d}$ withdrawal } & \multicolumn{2}{|l|}{ Retested $^{n}$} & \multicolumn{2}{|l|}{ First test ${ }^{b}$} \\
\hline & Control & Cocainc & Control & Cocaine & Control & Cocaine \\
\hline Ambulations & $111 \pm 15$ & $203 \pm 18 * *$ & $92 \pm 14$ & $104 \pm 16$ & $121 \pm 22$ & $116 \pm 18$ \\
\hline Total counts & $631 \pm 61$ & 1182 上 $97^{* *}$ & $586 \pm 62$ & $615 \pm 48$ & $671 \pm 72$ & $712 \pm 95$ \\
\hline Rears & $6.8 \pm 0.5$ & $9.2 \pm 0.6^{* *}$ & $7.4 \pm 0.4$ & $6.6 \pm 0.6$ & $6.9 \pm 0.7$ & $6.5 \pm 0.5$ \\
\hline Sniff-up & $6.1+0.9$ & $10.6+0.7^{* *}$ & $5.4 \pm 0.5$ & $6.1 \pm 0.6$ & $5.7 \pm 0.7$ & $6.1 \pm 0.7$ \\
\hline Sniff-down & $1.5 \pm 0.3$ & $2.8 \pm 0.4^{*}$ & $1.3 \pm 0.3$ & $1.4 \pm 0.3$ & $1.7 \pm 0.5$ & $1.4 \pm 0.4$ \\
\hline Head bobs & $0.4 \pm 0.3$ & $3.1 \pm 0.6^{* * *}$ & $0.3 \pm 0.2$ & $0.2 \pm 0.1$ & $0.4 \pm 0.3$ & $0.3 \pm 0.2$ \\
\hline
\end{tabular}

$* p<0.05, * * p<0.01, t$ test.

"These are the same rats that were tested following a $1 \mathrm{~d}$ withdrawal $(n=8 / \mathrm{group})$.

"These rats had not previously been tested ( $n=8 /$ group).

- Data indicate the number of $5 \mathrm{~min}$ intervals (of 18) that this behavior was present. 
repeated cocaine administration. To determine the specificity of such changes to cocaine-induced inhibition, we examined the inhibitory effects of GABA. In none of these experiments did we observe a significant difference between the effects of cocaine or GABA on spontaneously active and glutamate-driven neurons; thus, statistical comparisons are made with these two groups of cells pooled. As published previously, we saw no differences in the pharmacological responses of neurons within the shell and core regions of the NAc (White et al., 1993).

The effects of cocaine and GABA on the activity of glutamate-driven NAc neurons are illustrated in Figure 5. Both agents consistently inhibited NAc neurons in a current-dependent manner. Because these effects in control rats were highly similar at the various withdrawal times (see current-response curves in Figs. 6 and 7), only one example is provided (Fig. 5A). Cocaine induced inhibition was enhanced in rats following a $1 \mathrm{~d}$ withdrawal from repeated cocaine treatment (Fig. $5 B$ ) as compared to control rats (Fig. 5A). When the results from all cells in these two groups were averaged and plotted (Fig. 6A), it is apparent that repeated cocaine treatment significantly enhanced $\left(F_{1,27}=\right.$ $9.02, p=0.0058$ ) the inhibitory efficacy of cocaine. Following a 1 week withdrawal, NAc neurons in cocaine-treated rats were also significantly $\left(F_{1,24}=14.71, p \leq 0.0011\right)$ sensitized to the inhibitory effects of cocaine (see Figs. $5 C, 6 B$ ). Supersensitivity of NAc neurons to cocaine was also clearly evident $\left(F_{1,25}=\right.$ $9.86, p=0.0045$ ) after a one month withdrawal (see Figs. $5 D$, $6 C$ ), but not after a 2 month withdrawal (Figs. $5 E, 6 D ; F_{1,24}=$ $1.21, p=0.28$ ).

Surprisingly, the results indicated that at the one day withdrawal time, NAc neurons in cocaine-treated rats were also sensitized to the inhibitory effects of GABA (compare Fig. $5 \mathrm{~A}$ and $5 B$ ). When these results were plotted (see Fig. 7A) and analyzed, the enhanced response to GABA proved to be statistically significant $\left(F_{1,30}=8.286, p=0.0073\right)$. However, this effect was not observed at any other time point ( 1 week: $F_{1.24}=0.250, p$ $=0.624 ; 1$ month: $F_{1,26}=0.476, p=0.503$; and 2 months: $F_{1,25}$ $=0.013, p=0.877$, see Figs. $5 C-E$ and $7 B-D$ ).

Intravenous administration of cocaine also inhibits the majority of NAc neurons in our preparation (White et al., 1987, 1992; White, 1990). Because this route of administration would mimic our behavioral studies more closely, we also determined whether repeated cocaine administration would alter the responsiveness of NAc neurons to intravenous cocaine. We studied the effects of intravenous cocaine on NAc cells at both the one day and two month withdrawal times ( 14 rats/group) and compared them to a control group which consisted of eight rats withdrawn for $1 \mathrm{~d}$ and six rats withdrawn for 2 months from repeated vehicle injections. The results from these rats were pooled when it was determined that there was no significant difference between the effects of cocaine on NAc cells at these two withdrawal times $\left(F_{1,12}=0.65, p=0.43\right)$. In each of these three groups, nine of the cells were glutamate driven and the other five were spontaneously active. As in the iontophoretic studies described above, there were no significant differences (all $F_{1,12}, p>0.28$ ) between spontaneously active and glutamate-driven neurons in any of the three groups (control: $1.26 ; 1 \mathrm{~d}$ cocaine: $0.67 ; 2$ month cocaine: 0.81 ). Therefore, the results were combined for the purpose of statistical comparisons between the various treatment groups.

When tested $1 \mathrm{~d}$ after the last cocaine or vehicle injection, the inhibitory response of NAc neurons to intravenous cocaine was enhanced in cocaine-treated rats (Fig. $8 B$ ) as compared to control rats (Fig. 8A). No such effect was observed in rats with-

\section{A. Control/One Day}

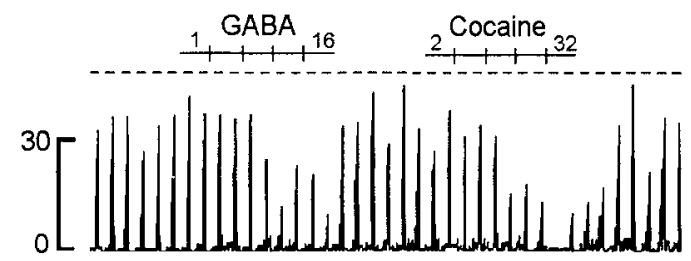

B. Cocaine/One Day
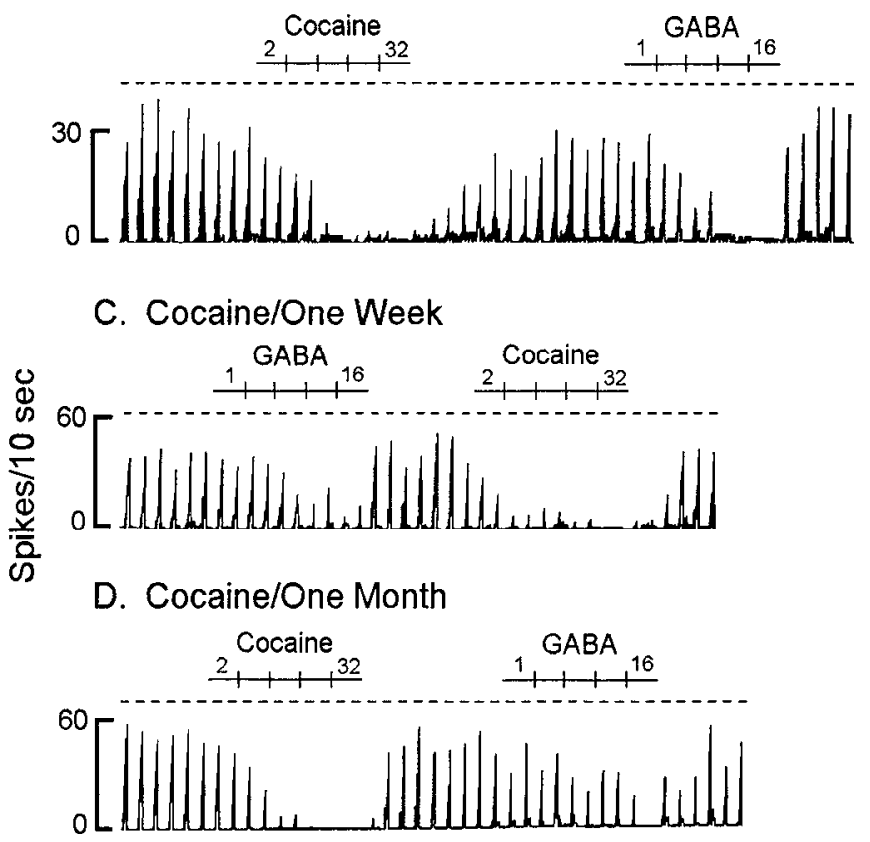

E. Cocaine/Two Months

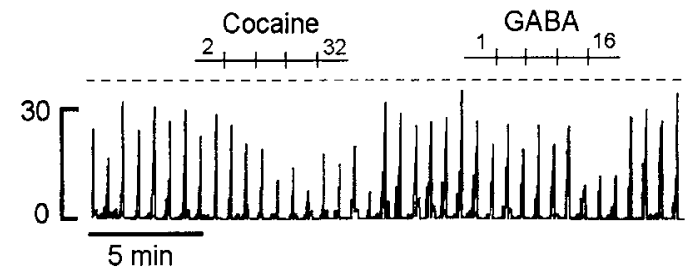

Figure 5. Cumulative rate histograms showing examples of repeated cocaine-induced alterations in the responses of NAc neurons to iontophoretically applied cocaine and GABA. $A$, NAc neurons from a control rat tested $18-24 \mathrm{hr}$ after the final injection of vehicle, illustrating the normal current-dependent inhibitory effects of GABA and cocaine. $B$ $E$, Effects of GABA and cocaine in rats that received repeated cocaine and were tested at various withdrawal times. Note the enhanced inhibitory efficacy of cocaine at all but the 2 month withdrawal time and the enhanced inhibitory efficacy of GABA only at the $1 \mathrm{~d}$ withdrawal time. All neurons pictured were driven to fire using $20 \mathrm{sec}$ pulses of glutamate (dashed lines). Horizontal bars indicate ejection duration and numbers represent current in nanoamperes (nA).

drawn for 2 months (Fig. 8C). When all NAc cells tested in these groups were averaged and plotted (Fig. 9), it was apparent that those recorded from cocaine-treated rats withdrawn for $1 \mathrm{~d}$ were significantly $\left(F_{2,39}=4.11, p=0.024\right)$ more sensitive to systemic cocaine than those tested in either control rats or in the cocaine-treated rats withdrawn for 2 months.

\section{Discussion}

Based upon our observations, behavioral sensitization following repeated cocaine administration appears to be a relatively per- 

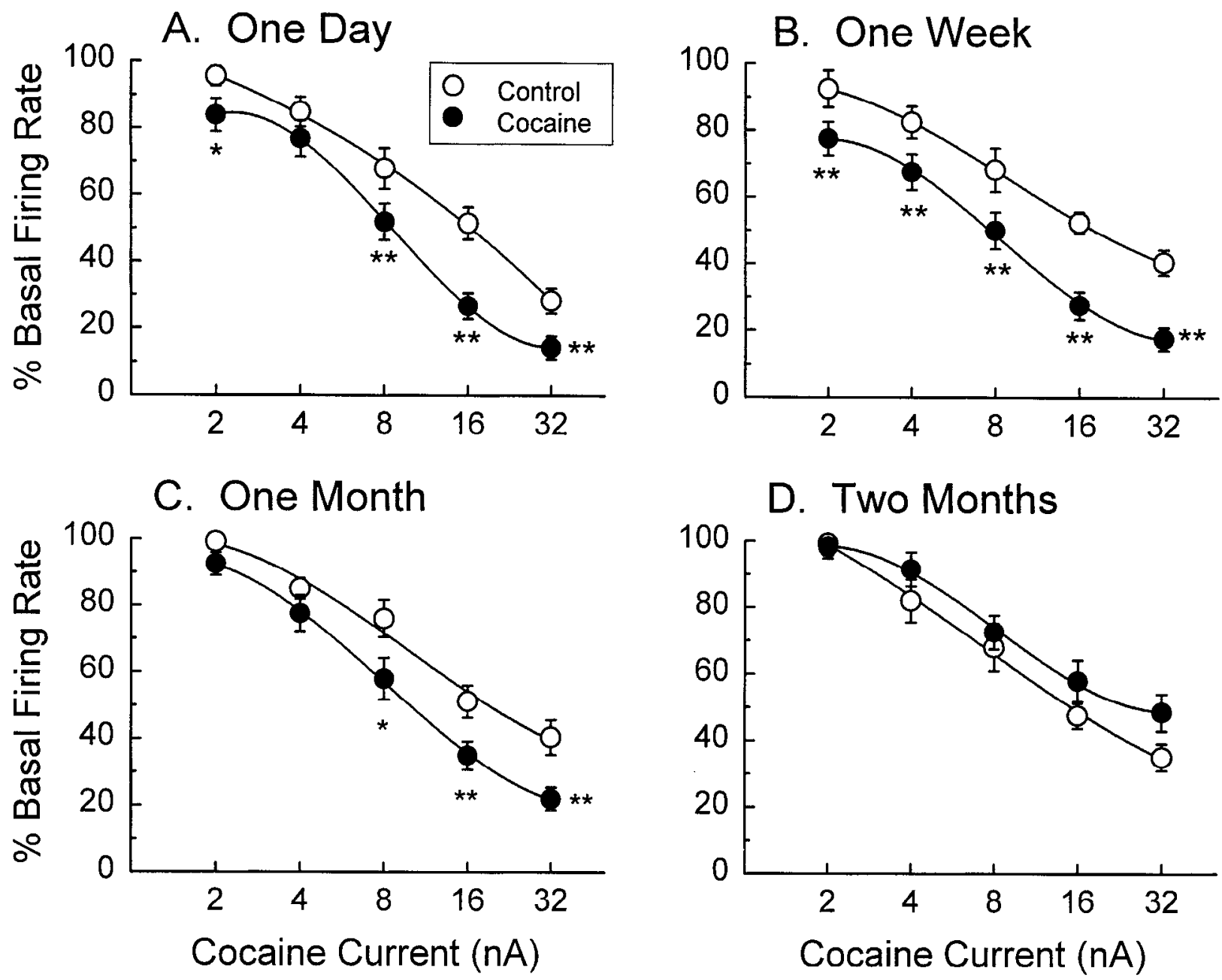

Figure 6. Effects of repeated cocaine on the sensitivity of NAc neurons to iontophoretically applied cocaine at various withdrawal times. These current response curves show that NAc neurons were more sensitive to cocainc at all but the 2 month withdrawal time. Each point represents the mean \pm SEM $\left(^{*}, p<0.05 ; * *, p<0.01\right.$, Dunnett's test). Sample sizes were as follows. $A$ : Control -17 cells, 6 spontaneously active (s.a) recorded from 7 rats; cocaine-18 cells, 5 s.a. from 7 rats. $B$ : Control $(14,3,6)$ and cocaine $(13,4,5)$. $C$ : Control $(14,4,6)$ and cocaine $(14,4,6)$. $D$, Control $(13,5,5)$ and cocaine $(14,5,6)$.

sistent, but not permanent effect. Using a treatment protocol designed to minimize context-dependent sensitization, we observed that sensitization was greatest at early withdrawal times ( $1 \mathrm{~d}, 1$ week) but waned with extended withdrawal $(1$ month, 2 months), suggesting a gradual decay in the mechanisms underlying cocaine sensitization. We also demonstrated enhanced sensitivity of NAc neurons to cocaine at early and intermediate, but not long, withdrawal times, an effect that is similar to our previous findings of supersensitive DA D1 receptor-mediated responses (Henry and White, 1991; White et al., 1995a). When viewed along with other work regarding cellular mechanisms underlying cocaine-induced locomotion and alterations in NAc neuronal activity (White et al., 1993; Xu et al., 1994), our findings suggest that increased DA D1 receptor sensitivity caused by repeated cocaine administration amplifies the essential role of this receptor system in cocaine-induced locomotion, leading to sensitization.

\section{Persistence of cocaine sensitization}

Our finding of a gradually waning sensitization was obtained from rats that were challenged with cocaine at only one withdrawal time. To our knowledge, the only other study that tested separate groups of rats at different cocaine withdrawal times revealed evidence for sensitization $23 \mathrm{~d}$ after the last cocaine injection (Kalivas and Duffy, 1993a). However, cocaine sensitization has been observed to last 54 to $98 \mathrm{~d}$ following treatment cessation when rodents are tested repeatedly during the treatment regimen and/or at various withdrawal times (Kilbey and Ellinwood, 1977; Shuster et al., 1977; Post et al., 1992). Given that transient sensitization can occur after only one exposure to cocaine (Weiss et al., 1989; Post et al., 1992; Jackson and Nutt, 1993), and that repeated association of cocaine with the test environment causes context-dependent sensitization (Post et al., 1992), it is possible that repeated challenges with cocaine at various withdrawal times were sufficient to maintain sensitization in the prior studies. Taken together, these findings are consistent with the notion that context-dependent sensitization is more persistent than context-independent sensitization (Post et al., 1992).

A conditioned increase in locomotor activity resulting from pairing of the test environment with cocaine is a well characterized aspect of cocaine sensitization (see Stewart and Vezina, 1988; Kalivas and Stewart, 1991; Post et al., 1992 for reviews). Such conditioned activity, like context-dependent sensitization, 

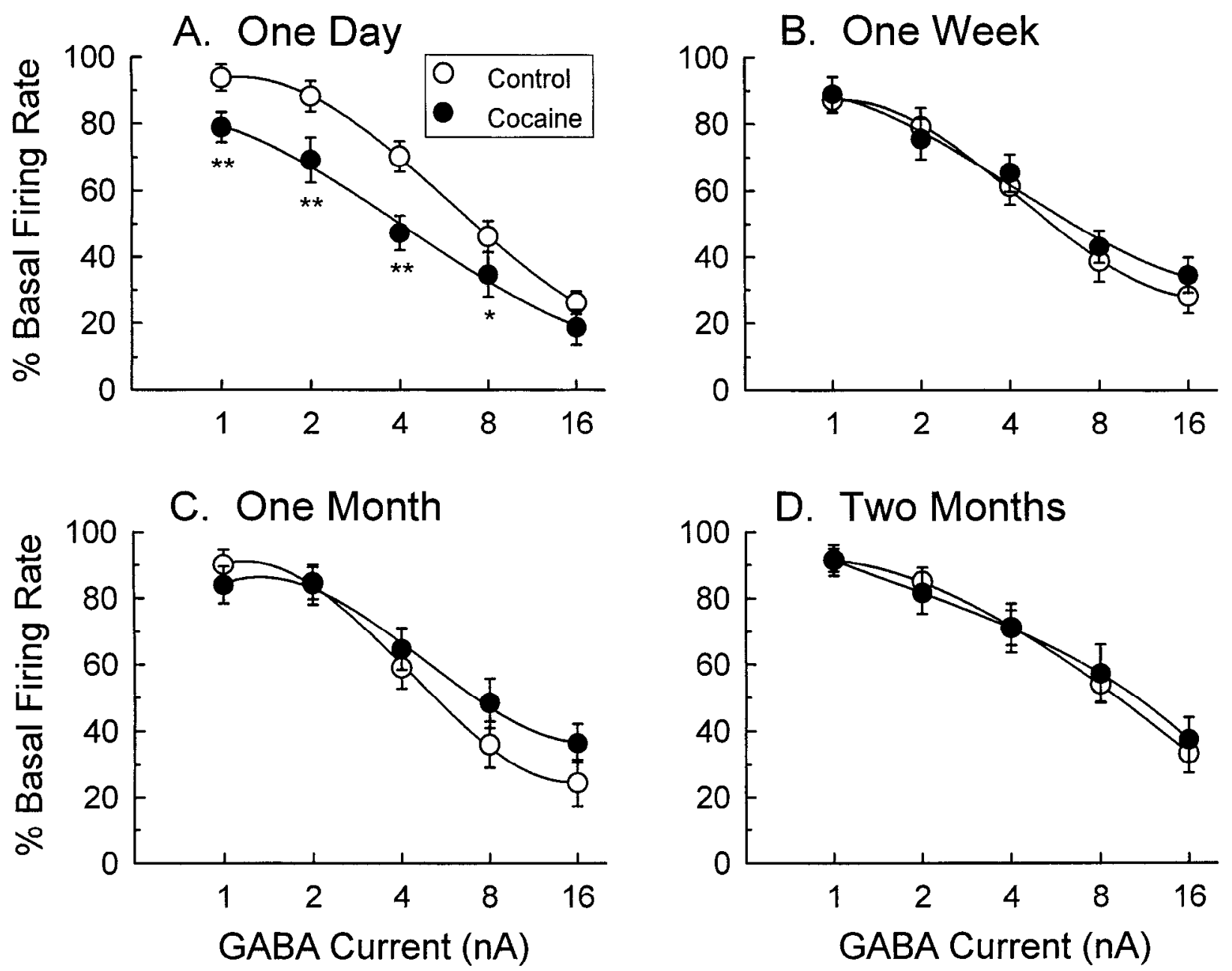

Figure 7. Effects of repeated cocaine on the sensitivity of NAc neurons to iontophoretically applied GABA at various withdrawal times. These are the same cells that were tested with iontophoretic cocaine (Fig. 6). The current-response curves show that NAc neurons were more sensitive to GABA only at the $1 \mathrm{~d}$ withdrawal time. Each point represents the mean \pm SEM $(*, p<0.05 ; * *, p<0.01$, Dunnett's test). See Figure 6 caption for sample sizes.

depends upon the degree of similarity between the injection and test environments (Weiss et al., 1989; Hinson and Poulos, 1981). Because these environments were markedly different in the present study (see Materials and Methods for details), it is not surprising that we found little evidence of conditioned increases in locomotor activity. In fact, only the $1 \mathrm{~d}$ withdrawal group exhibited heightened activity during saline tests on the day following cocaine challenges. Given that this group is the only one that did not receive a saline challenge test on the day before the cocaine challenge, it is possible that conditioned locomotion had been suppressed in all other cocaine groups by the explicit pairing of the test environment with the absence of cocaine. Whatever the case, our finding suggests that the sensitization observed with our treatment protocol was largely context-independent. However, traditional Pavlovian paradigms with appropriate controls would be required to confirm this suggestion.

In the animals tested for sensitization following the 1 month withdrawal period, enhanced locomotion was evident only in the between-groups comparison. This appeared to result from a smaller percentage of rats $(50 \%)$ showing sensitization, and from the decrease in activity in four of the six nonsensitized rats during the cocaine challenge as compared to their first test with cocaine. Although individual variation in the susceptibility to amphetamine sensitization has long been recognized (Leith and Kuczenski, 1982; Segal and Kuczenski, 1987a; Hooks et al., 1992), this factor has received relatively little attention in cocaine studies. Based upon estimates of session-to-session variability of cocaine responsiveness in nonsensitized rats, we only classified rats as sensitized when they exhibited at least a $50 \%$ increase in locomotion during the cocaine challenge as compared to the first cocaine test. Sensitization was evident in $75-$ $78 \%$ of the rats at early withdrawal times, a percentage that waned with longer withdrawal. Such individual animal analysis may prove useful in future studies of neuronal alterations associated with cocaine sensitization, inasmuch as nonsensitized, cocaine-exposed rats could serve as an additional control group.

Although our results indicate a lack of sensitization after two months of withdrawal from cocaine, at least two alternative interpretations of these data could be advanced. Because we tested these animals for sensitization only after the long withdrawal, when only 3 of the 12 rats were sensitized, it is possible that the other nine rats had never sensitized. Therefore, we tested another group of rats after both $1 \mathrm{~d}$ and 2 month withdrawals and found that the sensitization present after a $1 \mathrm{~d}$ withdrawal was no longer evident at 2 months. A second alternative interpretation is that the 2 month withdrawal group was actually 

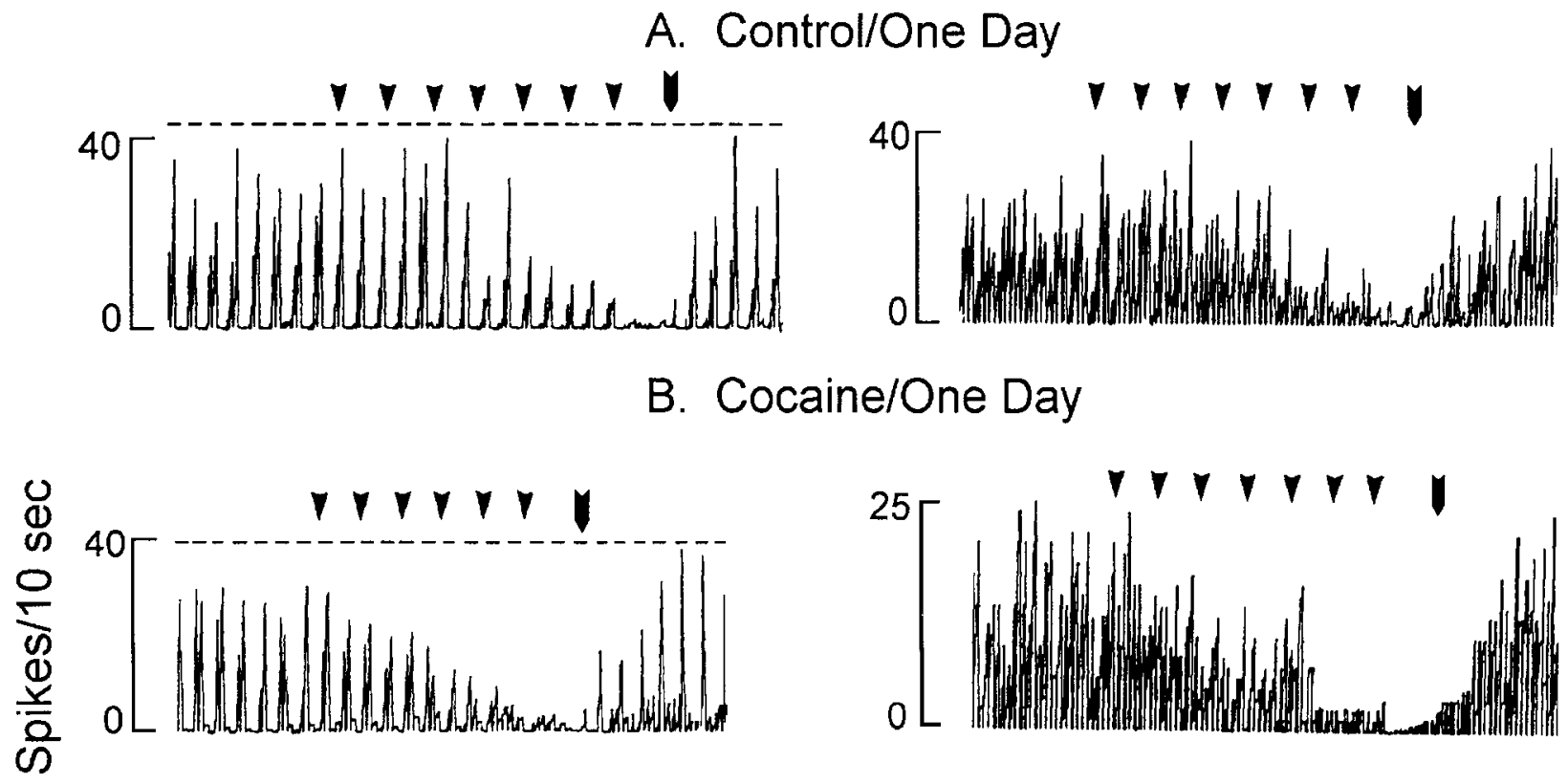

\section{Cocaine/Two Months}
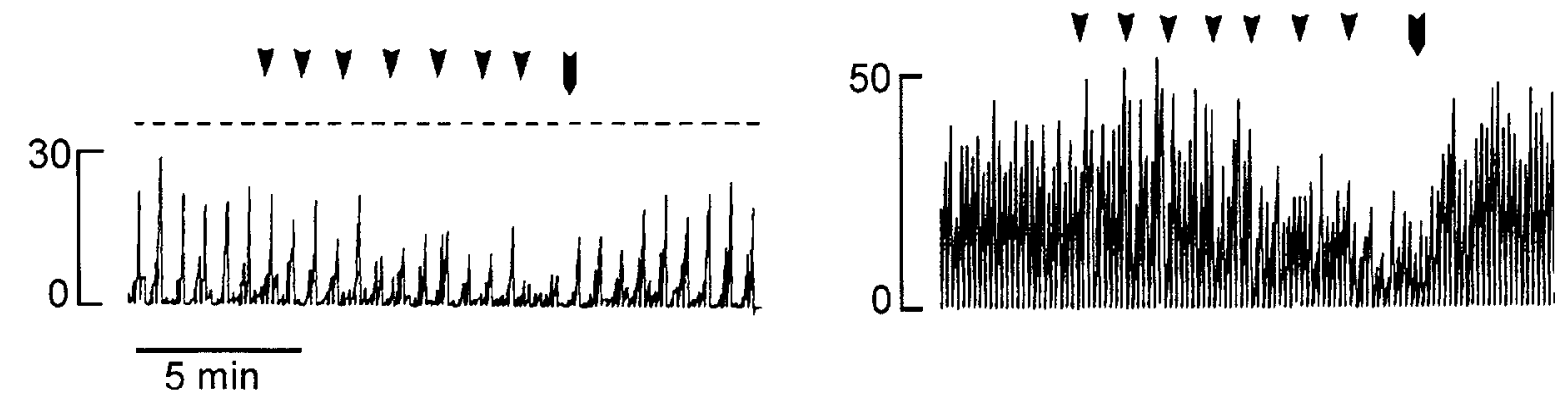

Figure 8. Examples illustrating the effect of repeated cocaine on the sensitivity of NAc neurons to intravenous (i.v.) cocaine following repeated administration of the cocaine vehicle $(A)$, a $1 \mathrm{~d}$ withdrawal from repeated cocaine administration $(B)$, or a 2 month withdrawal from repeated cocaine administration $(C)$. The left panels illustrate the effects of glutamate-driven neurons $(n=9$ cells and rats/group, dashed lines indicate glutamate pulses) whereas the right panels illustrate the effects on spontaneously active neurons ( $n=5$ cells and rats/group). Arrowheads indicate points where cocaine was administered, starting at an initial dose of $0.1 \mathrm{mg} / \mathrm{kg}$ and doubling at each arrow up to a cumulative dose of either 3.2 or $6.4 \mathrm{mg} / \mathrm{kg}$. Cocaine-induced inhibition was reversed by the DA D1 receptor antagonist SCH $23390(50 \mu \mathrm{g} / \mathrm{kg}$ i.v., at large arrowheads).

more sensitized. Amphetamine sensitization is often expressed as a reduction in locomotion due to the presence of more focused stereotyped behaviors (Segal et al., 1980; Robinson and Becker, 1986; Segal and Kuczenski, 1987a,b), and repeated cocaine treatment, at high doses, can induce more focused stereotyped behaviors (Post and Rose, 1976; Kilbey and Ellinwood, 1977a,b; Roy et al., 1978; Gale, 1984; Dow-Edwards et al., 1989). However, such a transition in the form of behavior could not explain our results because an increase in all behaviors was observed in sensitized rats after a $1 \mathrm{~d}$ withdrawal, whereas no behavior was enhanced after 2 months of withdrawal.

\section{Electrophysiological correlates of cocaine sensitization}

Repeated cocaine treatment rendered NAc neurons more sensitive to the inhibitory effects of cocaine, whether the drug was administered systemically or locally. Several factors might play a role in the enhanced inhibitory efficacy of cocaine, including alterations in the DA transporter (Izenwasser and Cox, 1990; Sharpe et al., 1991; Pilotte et al., 1994; Wilson et al., 1994) and in cocaine disposition (Ho et al., 1977; Estevez et al., 1979; Reith et al., 1987; Pettit et al., 1990; Pan et al., 1991). However, the time course of DA transporter alterations does not match that of sensitized electrophysiological responses in the NAc. Similarly, pharmacokinetic changes cannot explain the enhanced neuronal response to iontophoretically administered cocaine or to the DA D1 receptor agonist SKF 38393 (Henry and White, 1991). The similarity of the time courses for supersensitive cocaine and SKF 38393 effects within the NAc suggests that the enhanced inhibitory efficacy of cocaine results from synaptic DA stimulating supersensitive DA D1 receptors. The fact that the DA D1 receptor antagonist SCH 23390 reversed the inhibition produced by systemic cocaine supports this suggestion. However, the inhibition may not be mediated solely by DA D1 receptors. 5-HT receptor activation also plays a significant role in cocaine's effects on NAc neurons (White et al., 1993; Xu et al., 1994). In addition, DA D2-like receptor stimulation may also participate in the inhibitory effect, an action that would also be antagonized by SCH 23390 through prevention of the necessary "enabling" effect of DA D1 receptor stimulation for DA D2like receptor-mediated effects within the NAc (White, 1987; Wachtel et al., 1989; Xu et al., 1994).

Surprisingly, NAc neurons in cocaine-treated rats were also supersensitive to the inhibitory effects of GABA. However, unlike the supersensitivity to cocaine and SKF 38393 (Henry and 


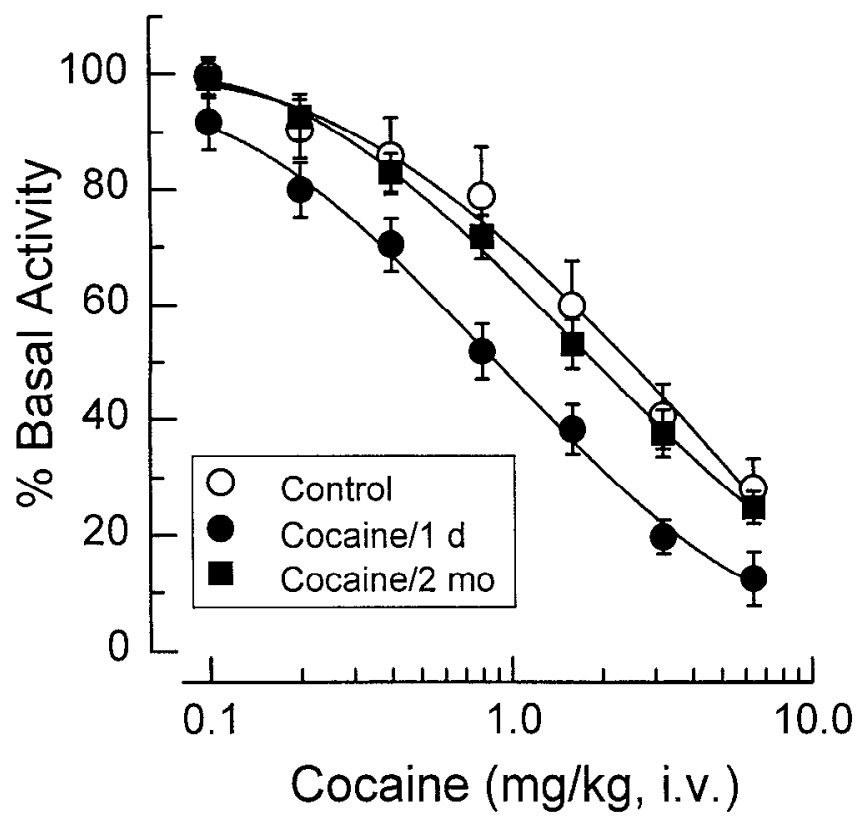

Figure 9. Effects of repeated cocaine on the sensitivity of NAc neurons to intravenous (i.v.) cocaine at $1 \mathrm{~d}$ and 2 month withdrawal times. These cumulative dose-response curves illustrate that NAc neurons were more sensitive to intravenous cocaine following a $1 \mathrm{~d}$, but not a 2 month withdrawal. Each point represents the mean \pm SEM. The $1 \mathrm{~d}$ withdrawal group was significantly more sensitive than the control group at all cocaine doses above $0.2 \mathrm{mg} / \mathrm{kg}$ ( $p<0.01$, Dunnett's).

White, 1991), the enhanced sensitivity to GABA was evident only after a $1 \mathrm{~d}$ withdrawal. Two potential explanations for this effect are: (1) enhanced GABA receptor sensitivity resulting from collateral inhibition between GABAergic neurons, and (2) a general decrease in membrane excitability. The latter explanation receives support from recent studies indicating reduced glutamate-induced excitation of NAc neurons in cocaine-sensitized rats (White et al. 1995b). Whatever the mechanism, it is apparent that the transient GABA supersensitivity did not play a significant role in the relatively persistent cocaine sensitization.

\section{Possible mechanisms of cocaine sensitization}

When viewed along with our previous electrophysiological studies (Henry and White, 1991, 1992; White et al., 1995a), as well as recent receptor binding (Alburges et al., 1993; Unterwald et al., 1994) and signal transduction results (Nestler et al., 1990; Terwilliger et al., 1991; Striplin and Kalivas, 1993), the present findings suggest that the enhanced bchavioral and clectrophysiological effects of cocaine following its repeated administration may result from a relatively persistent increase in the functional activity of DA D1 receptor-mediated processes within the NAc. These receptors play an essential role in the locomotor stimulant effects of a variety of drugs (see Waddington and Daly, 1993; White and $\mathrm{Hu}, 1993$ for recent reviews). In fact, mice lacking DA D1 receptors fail to exhibit hyperactivity following cocaine administration (Xu et al., 1994). Accordingly, enhanced transmission through DA D1 receptors seems certain to participate in the expression of sensitized locomotor stimulation (Henry and White, 1991; Henry and White, 1992; Unterwald et al., 1994), particularly during early periods of withdrawal when there is no enhancement of cocaine-induced increases in extracellular DA (Kalivas and Duffy, 1993a; Segal and Kuczenski, 1992b; Maisonneuve and Kreek, 1994). Indeed, the latter effect increases with withdrawal (Kalivas and Duffy, 1993a) whereas DA D1 receptor supersensitivity declines. Taken together, these findings support the hypothesis that alterations in dopamine release and postsynaptic responsiveness may participate to differing degress in the expression of cocaine sensitization at different points in lime (Kalivas and Stewart, 1991; Henry and White, 1992; Kalivas and Duffy, 1993a; Maisonneuve and Kreek, 1994). Although DA D1 receptors have also been suggested to participate in the development of behavioral sensitization (Kalivas and Stewart, 1991), this may not be true for cocaine because coadministration of SCH 23390 prevents expression (McCreary and Marsden, 1993) but not development of cocaine sensitization (Mattingly et al., 1994).

\section{Conclusions}

The findings that neither cocaine sensitization, when induced in a manner that minimized context dependency, nor certain physiological correlates of that sensitization were permanent effects suggest that the mechanisms underlying this form of plasticity are reversible. Available results suggest that context-dependent cocaine sensitization, engendered by repeated pairings of cocaine and the test environment, is more persistent than contextindependent sensitization (Post et al., 1992). It may be that context-dependent and context-independent aspects of cocaine sensitization are mediated by different, yet related, neuroadaptations occuring in converging neural networks. Alternatively, contextual cues might render the same neural alterations more persistent, or might engender neuronal events that trigger the expression of relevant neuroadaptations. Given that human cocaine abuse typically occurs in environments with distinct contextual cues, further analysis of cellular mechanisms underlying contextdependent and context-independent aspects of cocaine sensitization may yield important insights into the neurobiology of drug seeking behavior (Robinson and Berridge, 1993).

\section{References}

Ackerman JM, White FJ (1990) A10 somatodendritic dopamine autoreceptor sensitivity following withdrawal from repeated cocaine treament. Neurosci Lett 117:181-187.

Alburges MF, Narang N, Wamsley IK (1993) Alterations in the dopaminergic receptor system after chronic administration of cocaine Synapse 14:314-323.

Dougherty GG Jr, Ellinwood EH Jr (1981) Chronic d amphetamine in nucleus accumbens: lack of tolerance or reverse tolerance of locomotor activity. Life Sci 28:2295-2298.

Dow-Edwards D, Fico TA, Osman M, Gamagaris Z, Hutchings DE (1989) Comparison of oral and subcutaneous routes of cocaine administration on behavior, plasma drug concentration and toxicity in female rats. Pharmacol Biochem Behav 33:167-173.

DuMars LA, Rodger LD, Kalivas PW (1988) Behavioral cross-sensitization between cocaine and enkephalin in the A10 dopamine region. Behav Brain Res 27:87-91.

Estevez VS, Ho BT, Englert LF (1979) Metabolism correlates of cocaine-induced stereotypy in rats. Pharmacol Biochem Behav 10:?67271.

Gale K (1984) Catecholamine-independent behavioral and neurochemical effects of cocaine in rats. NIDA Res Monogr 54:323-332.

Henry DJ, Greene MA, White FJ (1989) Electrophysiological effects of cocaine in the mesoaccumbens dopamine system: repeated administration. J Pharmacol Exp Ther 251:833-839.

Henry DJ, White FJ (1991) Repeated cocaine administration causes persistent enhancement of D1 dopamine receptor sensitivity within the rat nucleus accumbens. J Pharmacol Exp Ther 258:882-890.

Henry DJ, White FJ (1992) Electrophysiological correlates of psychomotor stimulant-induced sensitization. Ann NY Acad Sci 654:88100 .

Higashi H, Inanaga I, Nishi S, Uchimura N (1989) Enhancement of 
dopamine actions on rat nucleus accumbens neurones in vitro after methamphetamine pre-treatment. J Physiol (Lond) 408:587-603.

Hinson RE, Poulos CX (1981) Sensitization to the behavioral effects of cocaine: modification by pavlovian conditioning. Pharmacol Biochem Behav 15:559-562.

Hitzemann R, Wu J, Hom D, Loh H (1980) Brain locations controlling the bchavioral cffects of chronic amphetamine intoxication. Psychopharmacology 72:93-101.

Ho BT, Taylor DL, Estevez VS, Englert LF, McKenna ML (1977) Behavioral effects of cocaine-metabolic and neurochemical approach. In: Cocaine and other stimulants (Ellinwood EH Jr, Kilbey MM, eds), pp 229-240. New York: Plenum.

Hooks MS, Jones GH, Liem BJ, Justice JB, Jr (1992) Sensitization and individual differences to IP amphetamine, cocaine, or caffeine following repeated intracranial amphetamine infusions. Pharmacol Biochem Behav 43:815-823.

Hope B, Kosofsky B, Hyman SE, Nestler EJ (1992) Regulation of immediate early gene expression and AP- 1 binding in the rat nucleus accumbens by chronic cocaine. Proc Natl Acad Sci USA 89:57645768 .

Hope BT, Nye HE, Kelz MB, Self DW, Iadarola MJ, Nakabeppu Y, Duman RS, Nestler EJ (1994) Induction of a long-lasting AP-1 complex composed of altered Fos-like proteins in brain by chronic cocaine and other chronic treatments. Neuron 13:1235-1244.

Horger BA, Shelton K, Schenk S (1990) Preexposure sensitizes rats to the rewarding effects of cocaine. Pharmacol Biochem Behav 37:707711.

Izenwasser S, Cox BM (1990) Daily cocaine treatment produces a persistent reduction of $\left[{ }^{3} \mathrm{H}\right]$ dopamine uptake in vitro in rat nucleus accumbens but not in striatum. Brain Res 531:338-341.

Jackson HC, Nutt DJ (1993) A single preexposure produces sensitization to the locomotor effects of cocaine in mice. Pharmacol Biochem Behav 45:733-735.

Kalivas PW, Duffy P (1993a) Time course of extracellular dopamine and behavioral sensitization to cocaine. I. Dopamine axon terminals. J Neurosci 13:266-275.

Kalivas PW, Duffy P (1993b) Time course of extracellular dopamine and behavioral sensitization to cocaine. II. Dopamine perikarya. J Neurosci 13:276-284

Kalivas PW, Stewart J (1991) Dopamine transmission in the initiation and expression of drug- and stress-induced sensitization of motor activity. Brain Res Rev 16:223-224.

Kalivas PW, Weber B (1988) Amphetamine injection into the Al0 dopamine region sensitizes rats to peripheral amphetamine and cocaine: J Pharmacol Exp Ther 245:1095-1102.

Kalivas PW, Dutty P, DuMars LA, Skinner C (1988) Behavioral and neurochemical effects of acute and daily cocaine administration in rats. J Pharmacol Exp Ther 245:485-492.

Kilbey MM, Ellinwood EH, Jr (1977a) Chronic administration of stimulant drugs: response modification. In: Cocaine and other stimulants (Ellinwood EH Jr, Kilbey MM, eds), pp 409-429. New York: Plenum.

Kilbey MM, Ellinwood EJ Jr (1977b) Reverse tolerance to stimulantinduced abnormal behavior. Life Sci 20:1063-1076.

Klcven MS, Perry BD, Woolverton WL, Seiden LS (1990) Effects of repeated injections of cocaine on $\mathrm{D}_{1}$ and $\mathrm{D}_{2}$ dopamine receptors in rat brain. Brain Res 532:265-270.

Kolta MG, Shreve P, Uretsky NJ (1989) Effect of pretreatment with amphetamine on the interaction between amphetamine and dopamine neurons in the nucleus accumbens. Neuropharmacology 28:9-14.

Koob GF (1992) Drugs of abuse: anatomy, pharmacology and function of reward pathways. Trends Pharmacol Sci 13:177-184.

Leith NJ, Kuczenski R (1982) Two dissociable components of behavioral sensitization following repeated amphetamine administration. Psychopharmacology 76:310-315.

Lett BT (1989) Repeated exposures intensify rather than diminish the rewarding effects of amphetamine, morphine, and cocaine. Psychopharmacology 98:357-362.

Maisonneuve IM, Kreek M-J (1994) Acute tolerance to the dopamine response induced by a binge pattern of cocaine administration in male rats: an in vivo microdialysis study. J Pharmacol Exp Ther 268:916921.

Mattingly BA, Hart TC, Lim K, Perkins C (1994) Selective antagonism of dopamine $\mathrm{D}_{1}$ and $\mathrm{D}_{2}$ receptors does not block the development of behavioral sensitization to cocaine. Psychopharmacology 114:239 242 .
Mayfield RD, Larson G, Zahniser N (1992) Cocaine-induced behavioral sensitization and $D_{1}$ dopamine receptor function in rat nucleus accumbens and striatum. Brain Res 573:331-335.

McCreary AC, Marsden CA (1993) Cocaine-induced behaviour: dopamine $\mathrm{D}_{1}$ receptor antagonism by SCH 23390 prevents expression of conditioned sensitisation following repeated administration of cocaine. Neuropharmacology 32:387-391.

Nestler EJ, Terwilliger RZ, Walker JR, Sevarino KA, Duman RS (1990) Chronic cocaine treatment decreases levels of the $G$ protein subunits $G_{i \alpha}$ and $G_{o x}$ in discrete regions of rat brain. J Neurochem 55:10791082 .

Pan H-T, Menacherry S, Justice JB Jr (1991) Differences in the pharmacokinetics of cocaine in naive and cocaine-experienced rats. $J$ Neurochem 56:1299-1306.

Paulson PE, Robinson TE (1991) Sensitization to systemic amphetamine produces an enhanced locomotor response to a subsequent intra-accumbens amphetamine challenge in rats. Psychopharmacology 104:140-141.

Paulson PE, Camp DM, Robinson TE (1991) Time course of transient behavioral depression and persistent behavioral sensitization in relation to regional brain monoamine concentrations during amphetamine withdrawal in rats. Psychopharmacology 103:480-492.

Paxinos G, Watson C (1986) The rat brain in stereotaxic coordinates New York: Academic

Peris J, Boyson SJ, Cass WA, Curella P, Dwoskin LP, Larson G, Lin L-II, Yasuda RP, Zahniser NR (1990) Persistence of neurochemical changes in dopamine systems after repeated cocaine administration. J Pharmacol Exp Ther 253:38-44.

Perugini M, Vezina $\mathbf{P}$ (1994) Amphetamine administered to the ventral tegmental area sensitizes rats to the locomotor effects of nucleus accumbens amphetamine. J Pharmacol Exp Ther 270:690-696.

Pettit HO, Pan H-T, Parsons LH, Justice JB Jr (1990) Extracellular concentrations of cocaine and dopamine are enhanced during chronic cocaine administration. J Neurochem 55:798-804.

Pilotte NS, Sharpe LG, Kuhar MJ (1994) Withdrawal of repeated intravenous infusions of cocaine persistently reduces binding to dopamine transporters in the nucleus accumbens of Lewis rats. J Pharmacol Exp Ther 269:963-969.

Post RM, Rose H (1976) Increasing effects of repetitive cocaine administration in the rat. Nature 260:731-732.

Post RM, Weiss SRB, Pert A (1992) Sensitization and kindling effects of chronic cocaine administration. In: Cocaine: pharmacology, physiology and clinical strategies (Lakoski JM, Galloway MP, White FJ, eds), pp 115-161. Boca Raton, FL: CRC.

Reith MEA, Benuck M, Lajtha A (1987) Cocaine disposition in the brain after continuous or intermittent treatment and locomotor stimulation in mice. J Pharmacol Exp Ther 243:281-287.

Roberts DCS (1992) Neural substrates mediating cocaine reinforcement: the role of monoamine systems. In: Cocaine: pharmacology, physiology, and clinical strategies (Lakoski JM, Galloway MP, White FJ, eds), pp 73-90. Boca Raton, FL: CRC.

Robinson TE, Becker JB (1986) Enduring changes in brain and behavior produced by chronic amphetamine administration: a review and evaluation of animal models of amphetamine psychosis. Brain Res Rev 11:157-198.

Robinson TE, Berridge KC (1993) The neural basis of drug craving: an incentive-sensitization theory of addiction. Brain Res Rev 18:247291.

Roy SN, Bhattacharyya AK, Pradham S, Pradham SN (1978) Behavioral and neurochemical effects of repeated administration of cocaine in rats. Neuropharmacology 17:559-564.

Segal DS, Kuczenski R (1987a) Individual differences in responsiveness to single and repeated amphetamine administration: behavioral characteristics and neurochemical correlates. J Pharmacol Fxp Ther 242:917-926.

Segal DS, Kuczenski R (1987b) Behavioral and neurochemical characteristics of stimulant-induced augmentation. Psychopharmacol Bull 23:417-424

Segal DS, Kuczenski R (1992a) In vivo microdialysis reveals a diminished amphetamine-induced dopamine response corresponding to behavioral sensitization produced by repeated amphetamine pretreatment. Brain Res $571: 330-337$.

Segal DS, Kuczenski R (1992b) Repeated cocaine administration induces behavioral sensitization and corresponding decreased extracel- 
lular dopamine responses in caudate and accumbens. Brain Res 577: 351-355.

Segal DS, Weinberger SB, Cahill JC, McCunney S (1980) Multiple daily amphetamine administration: behavioral and neurochemical alterations. Science 207:904-907.

Sharpe LG, Pilotte NS, Mitchell WM, De Souza EB (1991) Withdrawal of repeated cocaine decreases autoradiographic $\left[{ }^{3} \mathrm{H}\right]$ mazindol-labelling of dopamine transporter in rat nucleus accumbens. Eur J Pharmacol 203:141-144.

Shuster L, Yu G, Bates A (1977) Sensitization to cocaine stimulation in mice. Psychopharmacology 52:185-190.

Stewart J, Vezina P (1988) Conditioning and behavioral sensitization. In: Sensitization in the nervous system (Kalivas PW, Barnes CD, eds), pp 207-224. Caldwell, NJ: Telford.

Striplin CD, Kalivas PW (1993) Robustness of G protein changes in cocaine sensitization shown with immunoblotting. Synapse 14:1015.

Terwilliger R, Bcitner-Johnson D, Scvarino KA, Crain SM, Nestler EJ (1991) A general role for adaptations in G-proteins and the cyclic AMP system in mediating the chronic actions of morphine and cocaine on neuronal function. Brain Res 548:100-110.

Unterwald EM, Ho A, Rubenfeld JM, Kreek M-J (1994) Time course of the development of behavioral sensitization and dopamine receptor up-regulation during binge cocaine administration. J Pharmacol Exp Ther 270:1387-1396.

Vezina P, Stewart J (1990) Amphetamine administered into the ventral tegmental area but not to the nucleus accumbens sensitizes rats to systemic morphine: lack of conditioned effects. Brain Res 516:99106.

Wachtel SR, Hu X-T, Galloway MP, White FJ (1989) D1 dopamine receptor stimulation enables the postsynaptic, but not autoreceptor, effects of D2 dopamine agonists in nigrostriatal and mesoaccumbens dopamine systems. Synapse 4:327-346.

Waddington JL, Daly SA (1993) Regulation of unconditioned motor behaviour by $D_{1}: D_{2}$ interactions. In: $D_{1}: D_{2}$ dopamine receptor interactions (Waddington JL, ed), pp 51-78. San Diego: Academic.

Weiss F, Paulus MP, Lorang MT, Koob GF (1992) Increases in extracellular dopamine in the nucleus accumbens by cocaine are inversely related to basal levels: effects of acute and repeated administration. J Neurosci 12:4372-4380.

Weiss SRB, Post RM, Pert A, Woodward R, Murman D (1989) Context-dependent cocaine sensitization: differential effect of haloperidol on development versus expression. Pharmacol Biochem Behav 34: 655-661.

White FJ (1987) D-1 dopamine receptor stimulation enables the inhibition of nucleus accumbens neurons by a D-2 receptor agonist. Eur J Pharmacol 135:101-105.
White FJ (1990) Electrophysiological basis of the reinforcing effects of cocaine. Behav Pharmacol 1:303-315.

White FJ, Hu X-T (1993) Electrophysiological correlates of $\mathrm{D}_{1}: \mathrm{D}_{2}$ interactions. In: $\mathrm{D}_{1}: \mathrm{D}_{2}$ dopamine receptor interactions (Waddington $\mathrm{JL}$, ed), pp 79-114. San Diego: Academic.

White FJ, Wolf ME (1991) Psychomotor stimulants. In: The biological basis of drug tolerance and dependence (Pratt JA, ed), pp 153-197. London: Academic.

White FJ, Wachtel SR, Johansen PA, Einhorn LC (1987) Electrophysiological studies of the rat mesoaccumbens dopamine system: focus on dopamine receptor subtypes, interactions, and the effects of cocaine. In: Neurophysiology of dopaminergic systems: current status and clinical perspectives (Chiodo LA, Freeman AS, eds), pp 317 365. Detroit: Lakeshore.

White FJ, Henry DJ, Hu X-T, Jeziorski M, Ackerman JM (1992) Electrophysiological effects of cocaine in the mesoaccumbens dopamine system. In: Cocaine: pharmacology, physiology and clinical strategies (Lakoski JM, Galloway MP, White FJ, eds), pp 261-293. Boca Raton, FL: CRC.

White FJ, Hu X-T, Henry DJ (1993) Electrophysiological effects of cocaine in the rat nucleus accumbens: microiontophoretic studies. $\mathbf{J}$ Pharmacol Exp Ther 266:1075-1084.

White FJ, Hu X-T, Henry DJ, Zhang X-F (1995a) Neurophysiological alterations in the mesocorticolimbic dopamine system during repeated cocaine administration. In: The neurobiology of cocaine: cellular and molecular mechanisms (Hammer RP Jr, ed), pp 95-115. Boca Raton, FL: CRC.

White FJ, Hu X-T, Zhang X-F, Wolf ME (1995b) Repeated administration of cocaine or amphetamine alters neuronal responses to glutamate in the mesoaccumbens dopamine system. J Pharmacol Exp Ther 273:445-454.

Wilson JM, Nobrega JN, Carroll ME, Niznik HB, Shannak K, Lac ST, Pristupa ZB. Dixon LM, Kish SJ (1994) Heterogeneous subregional binding patterns of ${ }^{3} \mathrm{H}-\mathrm{WIN} 35,428$ and ${ }^{3} \mathrm{H}-\mathrm{GBR} 12,935$ are differentially regulated by chronic cocaine self-administration. J Neurosci $14: 2966-2979$

Wolf ME, White FJ, Nassar R, Brooderson RJ, Khansa MR (1992) Differential development of autoreceptor subsensitivity and enhanced dopamine release during amphetamine sensitization. $\mathbf{J}$ Pharmacol Exp Ther 264:249-255.

Wolf ME, White FJ, Hu X-T (1994) MK-801 prevents alterations in the mesoaccumbens dopamine system associated with behavioral sensitization to amphetamine. J Neurosci 14:1735-1745.

Woolverton WL, Cervo L, Johanson CE (1984) Effects of repeated methamphetamine administration on methamphetamine self-administration in rhesus monkeys. Pharmacol Biochem Behav 21:737-741.

$\mathrm{Xu}$ M, Hu X-T, Cooper DC, Moratalla R, Graybiel AM, White FJ, Tonegawa $S$ (1994) Elimination of cocaine-induced hyperactivity and dopamine-mediated neurophysiological effects in dopamine D1 receptor deficient mice. Cell 79:945-955. 